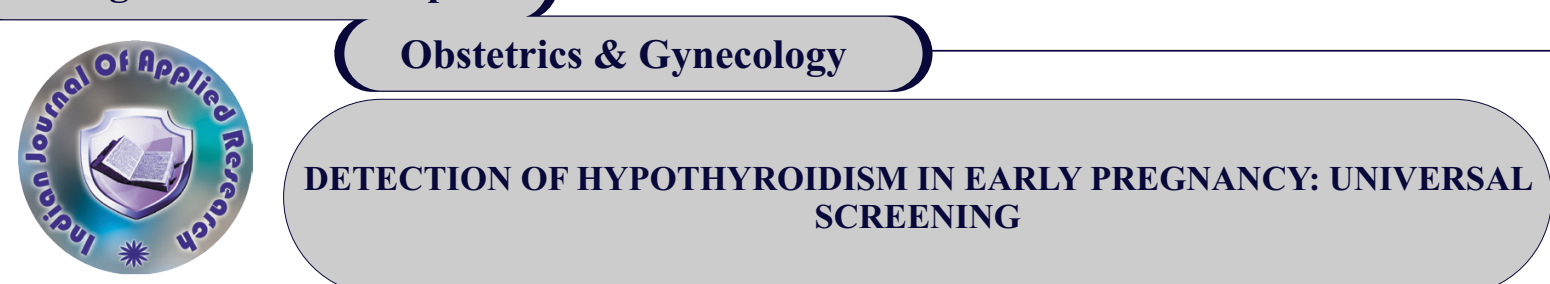

\section{Manpreet Kour}

Taranjeet Kour*
Senior Resident, Dartment Of Gyne And Obs, Artemis Hospital, Gurgaon, Haryana. Senior Consultant Medicine, Amandeep Hospital, Pathankot, Punjab. *Corresponding Author

\title{
ABSTRACT
}

Background: Thyroid dysfunction is one of the most common endocrine disorders in women of childbearing (1), second only to diabetes mellitus. The aim of this systemic review was to determine whether an increased maternal TSH level and normal serum $\mathrm{T} 4$ levels, as seen in $\mathrm{SCH}$, could also be associated with pregnancy complications.

Methods: This study was conducted in Nobel hospital,Pune January 2015 to July 2016 in all the pregnant women attending antenatal clinic in their first trimester of pregnancy. Data was collected on a pre-designed, pre-tested study proforma which includes socio-demographic information of patients, detailed clinical history and examinations of pregnant women and babies. Blood samples were taken under all aseptic precautions and were sent to laboratory of the institute for routine investigations and thyroid profile. Patients were followed up till delivery and babies were followed up till discharge from the hospital.

Results: This study was conducted in 220 patients in obstetrics and gynaecology department in Noble Hospital, Pune. Out of 220 cases, 198 cases were euthyroid, 13 cases were subclinical hypothyroid and 9 cases were overt hypothyroid. Hypothyroidism was found in 22(10\%) of pregnant women in their first trimester. Out of which, 13(5.91\%) had subclinical hypothyroidism and 9(4.09\%) had overt hypothyroidism. Majority of the patients $45.45 \%$ were in age group of 26-30years. $90.91 \%$ of hypothyroid patients had regular cycles and $9.09 \%$ had irregular cycles. Hypothyroidism was equally distributed between primi and multigravida patients. $31.82 \%$ of hypothyroid patients had previous history of abortions and $68.18 \%$ had no such history. $18.18 \%$ of hypothyroid patients had history of infertility and $31.82 \%$ had no history of infertility. AntiTPO was present in $9.09 \%$ and none of euthyroid patients. Maternal and Fetal complications were found more in hypothyroid patients than euthyroid patients.

Conclusion: Most of the patients in our study who have subclinical thyroid disease are asymptomatic, so screening is the most convenient method to identify such patients. Follow-up of abnormal TSH values with FT3 and FT4 may yield valuable results which could enable us for therapeutic intervention and may go a long way in preventing adverse pregnancy outcomes.

\section{KEYWORDS : Subclinical hypothyroidism, overt hypothyroidism, pregnancy, hypothyroidism}

\section{INTRODUCTION:}

Thyroid dysfunction is one of the most common endocrine disorders in women of childbearing ${ }^{(1)}$, second only to diabetes mellitus. Approximately $2-3 \%$ of women are diagnosed prenatally with abnormal thyroid function however; a greater number may go undetected due to lack of consensus on testing and treatment during pregnancy ${ }^{(2)}$.Subclinical hypothyroidism $(\mathrm{SCH})$ is defined as a high TSH concentration with a normal range of serum T4.Overt hypothyroidism $(\mathrm{OH})$ is defined as a high TSH concentration with low serum T4 concentrations . During pregnancy, the fetus relies heavily on its mother to synthesize essential hormones. As a result, hormone levels in the mother fluctuate greatly. For instance, the maternal thyroid gland must produce twice as much thyroid hormone during pregnancy in order to supply enough thyroid hormones for both the mother as well as the developing fetus ${ }^{(3)}$. However, if a pregnant woman has an undiagnosed thyroid disorder, she may not be able to provide an adequate amount of hormones, which is essential for both, her and her fetus. Ultimately, an insufficient amount of thyroid hormones may lead to severe pregnancy complications ${ }^{(4)}$ Even though the maternal thyroid is crucial for a fetus, universal screening for thyroid disorders has yet to be established ${ }^{(5)}$. The American College of Obstetricians and Gynecologists and the clinical practice guidelines of the Endocrine Society recommend to only screen for women who are presenting symptoms or have a history of thyroid Diseases. , the aim of this systemic review was to determine whether an increased maternal TSH level and normal serum T4 levels, as seen in SCH, could also be associated with pregnancy complications. Thyroid pathology worsens during pregnancy. Hypothyroidism can be pre-existent or may begin during pregnancy period. Hypothyroidism is difficult to be diagnosed during pregnancy as the signs can belong to pregnancy itself. Changes in thyroid function have a major negative impact on both mother and fetus. Of the different types of thyroid disorders, hypothyroidism is most common in women. The prevalence of $\mathrm{SCH}$ is higher than $\mathrm{OH}$, affecting $4-8 \%$ of US population. The physiologic changes of the thyroid system during pregnancy have been well elucidated. Total body thyroxine requirements are not static throughout gestation. Total body thyroxine concentrations must increase $20 \%-50 \%$ to maintain a euthyroid state ${ }^{(6)}$. In a healthy woman who becomes pregnant, the intact hypothalamic-pituitary-thyroid axis self-regulates to increase the thyroxine pool for the maternal-fetal unit. Additionally, hCG plays a major role in the stimulus of maternal thyroid hormone, especially throughout the first trimester of pregnancy. Together, placental hCG and pituitary TSH stimulate endogenous thyroxine production when an intact thyroid is present, and maintain a euthyroid state during gestation. The physiologic changes of the thyroid system during pregnancy have been well elucidated. Total body thyroxine requirements are not static throughout gestation. Total body thyroxine concentrations must increase $20 \%-50 \%$ to maintain a euthyroid state ${ }^{(7)}$. In a healthy woman who becomes pregnant, the intact hypothalamicpituitary-thyroid axis self-regulates to increase the thyroxine pool for the maternal-fetal unit. Additionally, hCG plays a major role in the stimulus of maternal thyroid hormone, especially throughout the first trimester of pregnancy. Together, placental hCG and pituitary TSH stimulate endogenous thyroxine production when an intact thyroid is present, and maintain a euthyroid state during gestation. The aim of this systemic review was to determine whether an increased maternal TSH level and normal serum T4 levels, as seen in SCH, could also be associated with pregnancy complications.

\section{AIMS AND OBJECTIVES:}

Primary Objective is to detect the incidence of hypothyroidism in early pregnancy. Secondary Objective is to study and compare feto maternal outcome of hypothyroidism patients with normal pregnant females.

\section{MATERIALAND METHODS}

Study Site: Noble Hospital, Pune.

Study Population: All pregnant women attending antenatal clinic in their first trimester of pregnancy.

Study Design: Prospective.

Study Type: Descriptive type of Observational study.

At the precision (Absolute allowable error) of $2 \%$ minimum 220 cases are required as sample size. It was further enhanced and rounded of to 400 patients considering $30 \%$ of dropout/attrition.

Time To Frame The Study: January 2015 to July 2016.

\section{Inclusion Criteria}

1) All pregnant women with gestational age less than 14 week

2) All Pregnant women irrespective of age group walking into obstetric OPD 
Volume - 10 | Issue - 10 | October - 2020 | PRINT ISSN No. 2249 - 555X | DOI : 10.36106/ijar

3) All Pregnant women irrespective of Parity.

\section{Exclusion Criteria}

1) All pregnant women who are already diagnosed as hypothyroid on treatment.

2)All women with Diabetes.

3) All women with Collagen disease.

4) All women with Heart disease.

\section{METHODOLOGY:}

Data was collected on a pre-designed, pre-tested study proforma which includes socio-demographic information of patients, detailed clinical history and examinations of pregnant women and babies.

All eligible consecutive patients coming to study location during study period were approached by Investigator herself and were explained about the nature and purpose of the study. After obtaining their informed written consent, detailed clinical history and thorough examination was done. Blood samples were taken under all aseptic precautions and were sent to the identified laboratory of the institute for routine investigations and thyroid profile. Patients were followed up till delivery and babies were followed up till discharge from the hospital. Data was collected and recorded. Random blood samples were collected from the patients in their first trimester of pregnancy upto 14 weeks.

TSH levels were assayed by competitive enzyme assay (ELISA) using commercially available kit (Accubind ELISA micro wells). Results of TSH were collected and recorded. The normal values are as:

TSH: $0.60-3.40 \mathrm{uIU} / \mathrm{ml}^{(8)}$

fT3: $4.1-4.4 \mathrm{pg} / \mathrm{ml}$

fT $4: 0.8-1.2 \mathrm{ng} / \mathrm{dl}$

\section{RESULTS}

Table 1. Prevalence Of Hypothyroidism

\begin{tabular}{|l|l|l|}
\hline Result & No. & \% \\
\hline Euthyroid & 198 & 90.00 \\
\hline Subclinical Hypothyroidism & 13 & 5.91 \\
\hline Overt Hypothyroidism & 9 & 4.09 \\
\hline Total & 220 & 100.00 \\
\hline
\end{tabular}

Prevalence of hypothyroidism was found to be $10 \%$, out of which $5.91 \%$ patients had subclinical hypothyroidism and $4.09 \%$ patients had overt hypothyroidism.

Table 2. Distribution Of Cases According To Thyroid Status \& Age Groups

\begin{tabular}{|l|l|l|l|l|l|l|}
\hline \multirow{3}{*}{ Age(Yrs) } & \multicolumn{4}{|l|}{ Status } & \multicolumn{2}{l|}{ Total } \\
\cline { 2 - 6 } & Euthyroid & \multicolumn{2}{l}{ Hypothyroid } & \multicolumn{2}{l|}{} \\
\cline { 2 - 6 } & No. & $\%$ & No. & $\%$ & No. & \% \\
\hline$\leq 20$ & 9 & 4.55 & 1 & 4.55 & 10 & 4.55 \\
\hline $21-25$ & 83 & 41.92 & 5 & 22.73 & 88 & 40.00 \\
\hline $26-30$ & 70 & 35.35 & 10 & 45.45 & 80 & 36.36 \\
\hline $31-35$ & 30 & 15.15 & 4 & 18.18 & 34 & 15.45 \\
\hline$>35$ & 6 & 3.03 & 2 & 9.09 & 8 & 3.64 \\
\hline Total & 198 & 100.00 & 22 & 100.00 & 220 & 100.00 \\
\hline
\end{tabular}

Maximum number of thyroid cases(45.45\%) were between the age group of 26-30years followed by patients(22.73\%) in age group of 2125 years in hypothyroid patients.

Table 3. Distribution Of Cases According To Thyroid Status And Menstrual Cycle

\begin{tabular}{|c|c|c|c|c|c|c|}
\hline \multirow[t]{3}{*}{ Cycles } & \multicolumn{4}{|c|}{ Status } & \multirow{2}{*}{\multicolumn{2}{|c|}{ Total }} \\
\hline & \multicolumn{2}{|c|}{\begin{tabular}{|l|} 
Euthyroid \\
\end{tabular}} & \multicolumn{2}{|c|}{ Hypothyroid } & & \\
\hline & \begin{tabular}{|l|} 
No. \\
\end{tabular} & $\%$ & No. & $\%$ & No. & $\%$ \\
\hline Irregular & 6 & 3.03 & 2 & 9.09 & 8 & 3.64 \\
\hline Regular & 192 & 96.97 & 20 & 90.91 & 212 & 96.36 \\
\hline Total & 198 & 100.00 & 22 & 100.00 & 220 & 100.00 \\
\hline
\end{tabular}

In hypothyroidism $90.91 \%$ patients had regular periods and $9.09 \%$ patients had irregular periods compared to $96.97 \%$ and $3.03 \%$ respectively in euthyroid patients. On statistically analysis this was not found to be statistically significant.

Table 4. Distribution Of Cases According To Thyroid Status And Gravidity

\begin{tabular}{|c|l|l|l|l|}
\hline Gravida & Status & Total & \\
\hline & Euthyroid & Hypothyroid & & \\
\hline \hline 36 & \multicolumn{1}{|c|}{ INDIAN JOURNAL OF APPLIED RESEARCH } \\
\hline
\end{tabular}

\begin{tabular}{|l|l|l|l|l|l|l|}
\hline & No. & \% & No. & \% & No. & $\%$ \\
\hline Primi & 79 & 39.90 & 11 & 50.00 & 90 & 40.91 \\
\hline Multi & 119 & 60.10 & 11 & 50.00 & 130 & 59.09 \\
\hline Total & 198 & 100.00 & 22 & 100.00 & 220 & 100.00 \\
\hline
\end{tabular}

Hypothyroidism was found to be equally distributed in primi and multigravida in hypothyroid patients and statistically not significant $(\mathrm{P}=0.493)$

Table 5. Distribution Of Cases According To Thyroid Status And Parity

\begin{tabular}{|l|l|l|l|l|l|l|}
\hline \multirow{3}{*}{ Parity } & \multicolumn{4}{|l|}{ Status } & \multicolumn{3}{l|}{ Hypothyroid } & \multicolumn{2}{l|}{} \\
\cline { 2 - 7 } & Euthyroid & Notal & \multicolumn{2}{l|}{} \\
\cline { 2 - 7 } & No. & $\mathbf{\%}$ & No. & $\%$ & No. & $\%$ \\
\hline Absent & 99 & 50.00 & 14 & 63.64 & 113 & 51.36 \\
\hline Present & 99 & 50.00 & 8 & 36.36 & 107 & 48.64 \\
\hline Total & 198 & 100.00 & 22 & 100.00 & 220 & 100.00 \\
\hline
\end{tabular}

In hypothyroidism $36.36 \%$ patients had history of parity and $63.64 \%$ had not, whereas in euthyroid patients parity was equally distributed and was not statistically significant $(\mathrm{p}=0.323)$.

Table 6. Distribution Of Cases According To Thyroid Status And Abortions

\begin{tabular}{|l|l|l|l|l|l|l|}
\hline \multirow{3}{*}{ Abortion } & \multicolumn{2}{|l|}{ Status } & \multicolumn{3}{l|}{ Total } \\
\cline { 2 - 7 } & \multicolumn{2}{|l|}{ Euthyroid } & \multicolumn{2}{l|}{} \\
\cline { 2 - 7 } & No. & $\mathbf{\%}$ & No. & $\%$ & No. & $\%$ \\
\hline Absent & 135 & 68.18 & 15 & 68.18 & 150 & 68.18 \\
\hline Present & 63 & 31.82 & 7 & 31.82 & 70 & 31.82 \\
\hline Total & 198 & 100.00 & 22 & 100.00 & 220 & 100.00 \\
\hline
\end{tabular}

In both hypothyroid and euthyroid patients $31.82 \%$ had past history of abortions and $68.18 \%$ had no such history and this was not found statistically significant $(\mathrm{p}=0.809)$.

Table 7. Distribution Of Cases According To Thyroid Status And Infertility

\begin{tabular}{|l|l|l|l|l|l|l|}
\hline $\begin{array}{l}\text { H/O } \\
\text { Infertility } \\
(\mathbf{P} / A)\end{array}$ & \multicolumn{4}{|l|}{ Status } & Euthyroid & \multicolumn{2}{l|}{ Hypothyroid } & \multicolumn{2}{l|}{ Total } \\
\cline { 2 - 7 } & No. & $\%$ & No. & $\%$ & No. & $\%$ \\
\hline Absent & 188 & 94.95 & 18 & 81.82 & 206 & 93.64 \\
\hline Present & 10 & 5.05 & 4 & 18.18 & 14 & 6.36 \\
\hline Total & 198 & 100.00 & 22 & 100.00 & 220 & 100.00 \\
\hline
\end{tabular}

$18.18 \%$ of hypothyroid patients had $\mathrm{h} / \mathrm{o}$ infertility compared to $5.05 \%$ of euthyroid patients and on statistical analysis this was not found to be statistically significant $(\mathrm{p}=0.053)$.

Table 8 . Distribution Of Cases According To Thyroid Status And Anti-TPO

\begin{tabular}{|l|l|l|l|l|l|l|}
\hline \multirow{2}{*}{$\begin{array}{l}\text { ANTI- } \\
\text { TPO }\end{array}$} & \multicolumn{4}{|l|}{ Status } & Hypothyroid & \multicolumn{2}{l|}{ Total } \\
\cline { 2 - 7 } & Euthyroid & \multicolumn{2}{|l|}{} \\
\cline { 2 - 7 } & No. & $\mathbf{\%}$ & No. & $\%$ & No. & $\%$ \\
\hline NIL & 198 & 100.00 & 20 & 90.91 & 218 & 99.09 \\
\hline Present & & 0.00 & 2 & 9.09 & 2 & 0.91 \\
\hline Total & 198 & 100.00 & 22 & 100.00 & 220 & 100.00 \\
\hline
\end{tabular}

Anti-TPO was present in $9.09 \%$ of hypothyroid patients. Anti-TPO was not present in any euthyroid patient. This was found to be statistically significant $(\mathrm{p}=0.002)$.

Table 9. Distribution Of Cases According To Thyroid Status And Maternal Outcome

\begin{tabular}{|l|l|l|l|l|l|l|}
\hline \multirow{2}{*}{ Maternal Outcome } & Status & \multicolumn{4}{l|}{ Total } \\
\cline { 2 - 7 } & Euthyroid & \multicolumn{3}{|l|}{ Hypothyroid } & \multicolumn{2}{l|}{} \\
\cline { 2 - 7 } & No. & $\%$ & No. & $\%$ & No. & $\%$ \\
\hline Nil & 104 & 52.51 & 0 & 0.00 & 104 & 46.26 \\
\hline $\begin{array}{l}\text { Gestational } \\
\text { Diabetes Melliru }\end{array}$ & 4 & 2.02 & 2 & 9.09 & 6 & 2.73 \\
\hline $\begin{array}{l}\text { Gestational } \\
\text { Hypertension }\end{array}$ & 44 & 22.22 & 5 & 22.73 & 49 & 22.27 \\
\hline Miscarriage & 19 & 9.60 & 7 & 31.82 & 26 & 11.82 \\
\hline Placenta Abruptio & 2 & 1.01 & 1 & 4.55 & 3 & 1.36 \\
\hline Placenta Previa & 3 & 1.52 & 1 & 4.55 & 4 & 1.82 \\
\hline $\begin{array}{l}\text { Postpartum } \\
\text { Haemorrhage }\end{array}$ & 3 & 1.52 & 1 & 4.55 & 4 & 1.82 \\
\hline PPROM & 4 & 2.02 & 2 & 9.09 & 6 & 2.73 \\
\hline Pre-Eclampsia & 7 & 3.54 & 1 & 4.55 & 8 & 3.64 \\
\hline
\end{tabular}


Volume - 10 | Issue - 10 | October - 2020 | PRINT ISSN No. 2249 - 555X | DOI : 10.36106/ijar

\begin{tabular}{|l|l|l|l|l|l|l|}
\hline Preterm Labor & 8 & 4.04 & 2 & 9.09 & 10 & 4.55 \\
\hline Total & 198 & 100.00 & 22 & 100.00 & 220 & 100.00 \\
\hline
\end{tabular}

Maternal outcomes were more adverse in hypothyroid than euthyroid patients.Miscarriages were found maximally (31.82\%) in hypothyroid patients and $9.60 \%$ in euthyroid patients followed by gestational hypertension $(22.73 \%)$ in hypothyroid patients. Relationship of maternal outcomes between euthyroid and hypothyroid patients was statistically found to be highly significant $(\mathrm{p}<0.001)$.

Table 10. Distribution Of Cases According To Thyroid Status And Mode Of Delivery

\begin{tabular}{|l|l|l|l|l|l|l|}
\hline \multirow{2}{*}{$\begin{array}{l}\text { Mode } \\
\text { Of } \\
\text { Delivery }\end{array}$} & \multicolumn{4}{|l|}{ Status } & Hypothyroid & \multicolumn{2}{l|}{ Total } \\
\cline { 2 - 5 } & Euthyroid & No. & No. & $\%$ & No. & $\%$ \\
\hline FTND & 89 & 44.95 & 8 & 36.36 & 97 & 44.09 \\
\hline LSCS & 85 & 42.93 & 7 & 31.82 & 92 & 41.82 \\
\hline MC & 19 & 9.60 & 7 & 31.82 & 26 & 11.82 \\
\hline PTVD & 5 & 2.53 & 0 & 0.00 & 5 & 2.27 \\
\hline Total & 198 & 100.00 & 22 & 100.00 & 220 & 100.00 \\
\hline
\end{tabular}

$31.82 \%$ (7) patients had undergone Lower segment caesarean section. $36.36 \%(8)$ patients had a vaginal delivery. $31.82 \%(7)$ patients had undergone miscarriage.Relationship between hypothyroid and euthyroid patients was found to be statistically significant.

Table 11. Distribution Of Cases According To Thyroid Status And Congenital Anomaly

\begin{tabular}{|c|c|c|c|c|c|c|}
\hline \multirow{3}{*}{$\begin{array}{l}\text { Congenital } \\
\text { Anomalies }\end{array}$} & \multicolumn{4}{|c|}{ Status } & \multirow{2}{*}{\multicolumn{2}{|c|}{ Total }} \\
\hline & \multicolumn{2}{|c|}{\begin{tabular}{|l|} 
Euthyroid \\
\end{tabular}} & \multicolumn{2}{|c|}{ Hypothyroid } & & \\
\hline & No. & $\%$ & No. & $\%$ & No. & $\%$ \\
\hline Absent & 177 & 98.88 & 15 & 100.00 & 192 & 98.97 \\
\hline Present & 2 & 1.12 & 0 & 0.00 & 2 & 1.03 \\
\hline Total & 179 & 100.00 & 15 & 100.00 & 194 & 100.00 \\
\hline
\end{tabular}

None of hypothyroid patient had congenital anomaly in fetus and $1.12 \%$ of euthyroid patients had congenital anomaly in fetus and this was not found to be statistically significant.(Those patients who had miscarriages, total 26 are excluded. So result is mentioned in remaining 194 patients).

Table 12. Distribution Of Cases According To Thyroid Status And Fetal Distress

\begin{tabular}{|c|c|c|c|c|c|c|}
\hline \multirow[t]{3}{*}{ Fetal Distress } & \multicolumn{4}{|c|}{ Status } & \multirow{2}{*}{\multicolumn{2}{|c|}{ Total }} \\
\hline & \multicolumn{2}{|c|}{ Euthyroid } & \multicolumn{2}{|c|}{ Hypothyroid } & & \\
\hline & No. & $\%$ & No. & $\%$ & No. & $\%$ \\
\hline Absent & 155 & 88.57 & 11 & 78.57 & 166 & 87.83 \\
\hline Present & 20 & 11.43 & 3 & 21.43 & 23 & 12.17 \\
\hline Total & 175 & 100.00 & 14 & 100.00 & 189 & 100.00 \\
\hline
\end{tabular}

Fetal distress was present in $21.43 \%$ of hypothyroid patients compared to $11.43 \%$ of euthyroid patients and this was not statistically significant $(p=0.499)$. (Those patients who had miscarriages, total 26 and had Intrauterine death, total 5 are excluded. So result is mentioned in remaining 189 patients).

Table 13. Distribution Of Cases According To Thyroid Status And Preterm Birth

\begin{tabular}{|l|l|l|l|l|l|l|}
\hline \multirow{2}{*}{$\begin{array}{l}\text { Pre } \\
\text { Term } \\
\text { Birth }\end{array}$} & \multicolumn{4}{|l|}{ Status } & Euthyroid & \multicolumn{2}{|l|}{ Hypothyroid } & \multicolumn{2}{l|}{} \\
\cline { 2 - 7 } & No. & $\%$ & No. & $\%$ & No. & $\%$ \\
\hline Absent & 167 & 93.30 & 13 & 86.67 & 180 & 92.78 \\
\hline Present & 12 & 6.70 & 2 & 13.33 & 14 & 7.22 \\
\hline Total & 179 & 100.00 & 15 & 100.00 & 194 & 100.00 \\
\hline
\end{tabular}

Pre-term birth was present in $13.33 \%$ of hypothyroid patients compared to $6.7 \%$ of euthyroid patients and was not found statistically significant $(\mathrm{p}=0.664)$. (Those patients who had miscarriages total 26 are excluded. So result is mentioned in remaining 194 patients).

Table 14. Distribution Of Cases According To Thyroid Status And LBW

\begin{tabular}{|l|l|l|l|l|l|l|}
\hline \multirow{3}{*}{ LBW } & \multicolumn{4}{|l|}{ Status } & \multicolumn{2}{l|}{ Total } \\
\cline { 2 - 5 } & \multicolumn{2}{|l|}{ Euthyroid } & No. & $\%$ & No. & $\%$ \\
\cline { 2 - 7 } & No. & $\%$ & 13 & 86.67 & 179 & 92.27 \\
\hline Absent & 166 & 92.74 & 13 & 13.33 & 15 & 7.73 \\
\hline Present & 13 & 7.26 & 2 & 100.00 & 194 & 100.00 \\
\hline Total & 179 & 100.00 & 15 & \\
\hline
\end{tabular}

Low birth weight was present in $13.33 \%$ of hypothyroid patients compared to $7.26 \%$ of euthyroid patients and was not found statistically significant. .(Those patients who had miscarriages, total 26 are excluded. So result is mentioned in remaining 194 patients).

Table 15. Distribution Of Cases According To Thyroid Status And Intrauterine Demise

\begin{tabular}{|l|l|l|l|l|l|l|}
\hline \multirow{2}{*}{$\begin{array}{l}\text { Intauterine } \\
\text { Demise }\end{array}$} & \multicolumn{2}{|l|}{ Status } & \multicolumn{2}{|l|}{ Hypothyroid } & \multicolumn{2}{|l|}{} \\
\cline { 2 - 6 } & Euthyroid & No. & $\%$ & No. & $\%$ \\
\cline { 2 - 7 } & No. & $\%$ & 14 & 93.33 & 189 & 97.42 \\
\hline Absent & 175 & 97.77 & 14 & 6.67 & 5 & 2.58 \\
\hline Present & 4 & 2.23 & 1 & 100.00 & 194 & 100.00 \\
\hline Total & 179 & 100.00 & 15 &
\end{tabular}

IUD was seen in $6.67 \%$ of hypothyroid patients compared to $2.25 \%$ of euthyroid patients and was not found statistically significant $(\mathrm{p}=0.847)$. (Those patients who had miscarriages, total 26 are excluded. Therefore, result is mentioned in remaining 194 patients).

\section{DISCUSSION:}

Thyroid disorders are common endocrine problems in pregnant women. It is now well establish that both overt and subclinical thyroid dysfunctions have adverse effect on maternal and fetal outcome. However, pregnant women with thyroid disease do not always develop symptoms, and when they do, these symptoms can sometime be attributed to pregnancy itself and can only get exaggerated. In these situations, accurate laboratory assessment of maternal thyroid function assumes a great importance. In the present study, 220 pregnant women, reported to out patient department from January, 2015 to July 2016 were put for analysis for thyroid function. 198 pregnant women were found to be euthyroid. Subclinical hypothyroidism was identified in $13(5.91 \%)$ pregnant women and overt hypothyroidism in 9 (4.09\%) pregnant women.

Prevelance of hypothyroidism percentage

\begin{tabular}{|l|l|}
\hline Present study & $10 \%$ \\
\hline Padmavathi $^{(9)}$ & $6.6 \%$ \\
\hline Mandal $^{(10)}$ & $32.94 \%$ \\
\hline Hou MQ & \\
\hline Sapana.C Shah & $(12)$ \\
\hline ZY Shan $^{(13)}$ & $4.9 \%$ \\
\hline Klein $^{(14)}$ & $9 \%$ \\
\hline
\end{tabular}

In our study maximum number $(41.92 \%)$ of hypothyroid cases are in age group of 21-25 years which was comparable to the study conducted by Rohan Dineshbhai Patel wt al ${ }^{(15)}$ in which $49 \%$ of the hypothyroid patients were in age group of 21-25 years.In our study irregular cycles were found more $(9.09 \%)$ in hypothyroid patients as compared to euthyroid patients in which it was found in $3.03 \%$. These findings were lower than that found in study conducted by Krassas GE et $\mathrm{al}^{(16)}$ in which irregular periods were found in $23.4 \%$ of hypothyroid patients and $8.4 \%$ of euthyroid patients. In our study Hypothyroidism was found to be equally $(50 \%)$ distributed among primigravida and multigravida patients. In study conducted by Sapana C. Shah ${ }^{(17)}$ Hypothyroidism was found more $(59.3 \%)$ in multigravida patients and $40.7 \%$ of hypothyroid patients were primigravida.

Maternal outcomes in terms of miscarriage, gestational hypertension, gestational diabetes, placenta previa, placenta abruption, postpartum haemorrhage, PPROM, pre-eclampsia, pre-term labor and fetal outcomes in terms of fetal distress in labor, preterm birth, low birth weight, fetal death, and congenital anomalies were studied in pregnant women diagnosed with hypothyroidism and euthyroid pregnant women. Comparison of maternal outcome between hypothyroid and euthyroid patients was found to be statistically significant $(\mathrm{p}<0.001)$ in our study. In our study, incidence of miscarriage was $31.82 \%$ in hypothyroid patients which was comparable to Abalovich ${ }^{(18)}$ which showed that untreated hypothyroidism, subclinical or overt, at the time of conception is associated with miscarriage rate of $31.4 \%$ compared with $4 \%$ in euthyroid subjects at conception and Nambiar ${ }^{(19)}$ which found a significant association of high rate of miscarriage with hypothyroidism. Wang et $\mathrm{al}^{(20)}$ also reported that the incidence of spontaneous abortions in the subclinical hypothyroidism group was higher than in the normal TSH group $(15.48 \%$ versus $8.86 \%)$. In the present study gestational hypertension was seen in $22.73 \%$ of hypothyroid patients which was comparable to the study conducted by Leung et $\mathrm{al}^{(21)}$ in which it was reported that gestational hypertension was significantly more common in the overt $(22 \%)$ and subclinical hypothyroid $(15 \%)$ patients than in the general population $(7.6 \%)$ and 
Casey et al ${ }^{(22)}$ reported that gestational hypertension occurred not only in overt hypothyroidism (36.1\%) but also in subclinical hypothyroidism compared to general population. Women who had lowest TSH levels had an incidence of hypertensive disorders of $6.2 \%$ as compared with $8.5 \%$ of euthyroid women and $10.9 \%$ of subclinical hypothyroid women. These differences when unadjusted were significant. In our study maternal complications like pre-eclampsia, placental abruption, post-partum haemorrhage were found in $9.09 \%, 4.55 \%$ and $4.55 \%$ respectively and fetal complication like low birth weight was found in $13.3 \%$ which were lower than that found by Davis ${ }^{(23)}$ in which maternal complications were common and included preeclampsia (44\%), placental abruption $(19 \%)$, postpartum hemorrhage $(19 \%)$ and fetal complication low birth weight was found in $31 \%$. Low birth weight found in our study $(13.3 \%)$ found to be comparable with the study conducted by Singh $\mathrm{G}$ et al ${ }^{(24)}$ in which $18.86 \%$ women delivered low birth weight babies. Aditya et $\mathrm{al}^{(25)}$ also reported that both subclinical and overt hypothyroidism were associated with significantly increased low birth weight rates.

In our study placental abruption was found in $4.55 \%$ of hypothyroid patients while Casey et $\mathrm{al}^{(22)}$ reported that pregnancies in women with subclinical hypothyroidism were three times more likely to be complicated by placental abruption and it was statistically significant $(\mathrm{p}=0.026)$.PROM found in our study was higher $(9.09 \%)$ than that found in study conducted by Singh G. et $\mathrm{al}^{(24)}$ in which PPROM was found in $5.71 \%$ of hypothyroid patients.In present study gestational diabetes was found more in hypothyroid $(9.09 \%)$ compared to euthyroid patients $(2.02 \%)$. Sahu et $\mathrm{al}^{(26)}$ also found gestational diabetes significantly more in overt hypothyroidism group $(\mathrm{P}=0.04)$. In our study pre-term birth was found in $9.09 \%$ of hypothyroid patients which was twice that found in euthyroid patients which was similar to Casey ${ }^{(22)}$.In our study anti-TPO was present in $9.09 \%$ of hypothyroid patients which was lower than that found by Pradhan ${ }^{(27)}$ in which amongst the women with hypothyroidism, TPO positive were $40 \%$.In our study, it was found that maternal hypothyroidism early in pregnancy is strongly associated with fetal distress in labor similar to that found by Wasserstrum and Anancia ${ }^{(28)}$. In our study maximum number $(36.36 \%)$ of hypothyroid patients underwent normal vaginal delivery and $31.82 \%$ of hypothyroid patients underwent lower segment cesarean section which is against that found in study conducted bt Sapana et a ${ }^{(13)}$. Sahu et $\mathrm{al}^{(26)}$ reported that cesarean section rate for fetal distress was significantly higher among pregnant subclinical hypothyroid women.

\section{SUMMARYAND CONCLUSION:}

This study was conducted in 220 patients in obstetrics and gynaecology department in Noble Hospital, Pune. Out of 220 cases, 198 cases were euthyroid, 13 cases were subclinical hypothyroid and 9 cases were overt hypothyroid. Hypothyroidism was found in $22(10 \%)$ of pregnant women in their first trimester. Out of which, $13(5.91 \%)$ had subclinical hypothyroidism and $9(4.09 \%)$ had overt hypothyroidism. Majority of the patients $45.45 \%$ were in age group of $26-30$ years. $90.91 \%$ of hypothyroid patients had regular cycles and $9.09 \%$ had irregular cycles. Hypothyroidism was equally distributed between primi and multigravida patients. $31.82 \%$ of hypothyroid patients had previous history of abortions and $68.18 \%$ had no such history. $18.18 \%$ of hypothyroid patients had history of infertility and $31.82 \%$ had no history of infertility. Anti-TPO was present in $9.09 \%$ and none of euthyroid patients. Maternal and Fetal complications were found more in hypothyroid patients than euthyroid patients. It is very ideal to subject a pregnant woman for thyroid screening as early as possible in pregnancy. Most of the patients in our study who have subclinical thyroid disease are asymptomatic, so screening is the most convenient method to identify such patients. Follow-up of abnormal TSH values with FT3 and FT4 may yield valuable results which could enable us for therapeutic intervention and may go a long way in preventing adverse pregnancy outcomes. Therapeutic interventions should be initiated at the earliest for favourable pregnancy outcomes.It is ideal to screen all women preconceptionally whenever feasible. Preconceptional evaluation of the thyroid hormones is very important for the women who are trying for pregnancy, to achieve the euthyroid status, which will in the true sense prevent the effect of hypothyroidism on the fetus rather than screening in the first trimester and starting the treatment after detection of the condition.It is found that those patients who have severe maternal hypothyroidism early in gestation is strongly associated with fetal complications. Therefore, to prevent these complications theses patients should be identified and treated at the earliest.To conclude: Thyroid screening tests should be made mandatory to include in first trimester antenatal profile.

\section{REFERENCES}

1. Nader S, Creasy R, Resnik R, Iams J, editors. Thyroid Disease and Pregnancy. MaternalFetal Medicine. 5th ed: Saunders; 2004.p. 1063-1081.

2. Stagnaro-Green A, Abalovich M, Alexander E, Azizi F, Mestman J, Negro R, et al. Guidelines of the American Thyroid Association for the diagnosis and management of thyroid disease during pregnancy and postpartum. Thyroid 2011;21(10): 1081-125.

3. Hirsch, D., Levy, S., Nadler, V., Kopel, V., Shainberg, B., \& Toledano, Y et al. Pregnancy outcomes in women with severe hypothyroidism. European Journal Of Endocrinology 2014; 169(3):313-320.

4. Abalovich, M., Gutierrez, S., Alcaraz, G., Maccallini, G., Garcia, A., \& Levalle, O et al. Overt and Subclinical Hypothyroidism Complicating Pregnancy. Thyroid 2002; 12(1): 63-68.

5. Goldsmith RE, McAdams AJ, Larsen PR, McKenzie M, Hess EV.et al. Familial autoimmune thyroiditis: maternal-fetal relationship and the role of generalized autoimmune thyroiditis: maternal-fetal relationship an
autoimmunity. JClin Endocrinol Metab.1973;37:265-275

6. Alexander EK. Marqusee E. Lawrence J. Jarolim P. Fischer GA. Larsen PR. Timing and magnitude of increases in levothyroxine requirements during pregnancy in women with hypothyroidism. N Engl J Med. 2004;351:241-249.

7. Mandel SJ. Larsen PR. Seely EW. Brent GA. Increased need for thyroxine during pregnancy in women with primary hypothyroidism. NEngl J Med. 1990;323:91-96

8. Ajmani, S., Aggarwal, D., Bhatia, P., Sharma, M., Sarabhai, V., \& Paul, M.e al.Prevalence of Overt and Subclinical Thyroid Dysfunction Among Pregnant Women and Is Effect on

9. Padmavathi K, Prasanna Ch et al. Incidence of hypothyroidism in antenatal women with maternal and fetal outcome. 2015;14(4):14-18

10. Mandal RC,Bhar D,Das A et al.Subclinical hypothyroidism in pregnancy.J Nat Sci Biol Med. 2016 Jan-Jun;7(1):80-4.

11. Hou MQ, Wanq ZJ, Hou KZ et al. Influence of Hypothyroidism on pregnancy outcome and fetus during pregnancy.Zhonghua Liu Xing Bing Xue Za Zhi. 2016 may;37(5):722-4.

12. Sapana C. Shah et al.PREVALENCE OF HYPOTHYROIDISM DURING PREGNANCY . International Journal of Basic and Applied Medical Sciences. 2014; 4 (3):130-134.

13. Shan Z.Y,Chen Y.Y, Tang W.P et al. A study of maternal thyroid hormone deficiency during the first half of pregnancy in China. European journal of clinical investigation.Jan, 2009;39:37-42

14. R.Z.Klein, J.E.Haddow, J.D.Falx et al. Prevalence of thyroid deficiency in pregnant women.ClinicalEndocrinology. 1991;35(1):41-46.

15. Rohan Dineshbhai Patel, Kruti J. Deliwala, Parul T. Shah, Rajani K. Singh. Fetomaternal outcome of thyroid disorder in pregnancy.International Journal of Reproduction, Contraception, Obstetrics and Gynecology.2016;5(12):4466-4469.

16. Krassas GE et al.Disturbances of menstruation in hypothyroidism. Clin Endicrinol. 1999 May;50(5):655-9

17. Sapana C. Shah et al.PREVALENCE OF HYPOTHYROIDISM DURING PREGNANCY . International Journal of Basic and Applied Medical Sciences. 2014; 4 (3): $130-134$

18. Abalovich M, Amino N, Barbour LA et al. Management of thyroid dysfunction during pregnancy and postpartum: An Endocrine Society clinical practice guidelines. J Clin Endocrinol Metabol 2007; 92:S1-S47.

19. Nambiar V, Jagtap VS, Sarathi V et al. Prevalence and impact of thyroid disorders on maternal outcome an Asian Indian pregnant women.Journal of thyroid research.vol 2011, article ID 429097, 6 pages.

20. Wang S, Teng WP, Li JX et al. Effects of maternal subclinical hypothyroidism on obstetrical outcome during early pregnancy. J Endocrinol Invest. 2012;35(3):322-325.

21. Leung, Anna S, Miller et al. Perinatal outcome in hypothyroid pregnancies. Obstet and Gynecol.1993; 81(3):323-481.

22. Casey, Brian M. MD; Dashe, Jodi S. MD; Wells, C Edward MD; et al. Subclinical hypothyroidism and pregnancy outcome. Obstetrics \& Gynecology. 2005;105(2):239-245

23. Davis LE, Leveno KJ, Cunningham FG. Hypothyroidism complicating pregnancy. Obstet Gynecol .1988;72(1):108-112.

24. Singh G et al. Maternal and fetal outcome in subclinical hypothyroidism in Jammu region, North India.Int J Reprod Contracept Obstet Gynecol. 2016 Jul;5(7):2362-2366.

25. Aditya K, Gupta V, Achint S, Dhar T, Jacob JJ and Awasthi K. Pregnancy loss an neonatal outcomes in women with thyroid dysfunction in the first trimester of pregnancy. Endocr Rev. 2012;33.

26. Sahu, M., Das, V., Mittal, S., Agarwal, A., \& Sahu, M. et al. Overt and subclinical thyroid dysfunction among Indian pregnant women and its effect on maternal and fetal outcome. Arch Gynecol Obstet 2009; 281(2): 215-220.

27. Pradhan M, Anand B, Singh N, Mehrotra M et al. Thyroid peroxidase antibody in hypothyroidism: It's effect on pregnancy.J Matern-fetal and neonata med.2013;26(6):581-583

28. Wasserstrum N, Ananla CA et al. Perinatal consequences of maternal hypothyroidism in early pregnancy and inadequate replacement. Clin Endocrinol.1995;42(4):353-358. 